and more uniform products for a given raw material and, without risk, allow some economies to be introduced in the allocation of protein concentrates for practical animal feeding.

\title{
REFERENCES
}

Becker, D. E., Lassiter, J. W., Terrill, S. W. \& Norton, H. W. (1954). F. Anim. Sci. 13, 6r I Brinegar, M. J., Williams, H. H., Ferris, F. H., Loosli, J. K. \& Maynard, L. A. (r95o). f. Nutr. 42, I29.

Carpenter, K. J. (1954). World's Poult. Congr. x. Edinburgh, p. 125.

Carpenter, K. J., Duckworth, J. \& Ellinger, G. M. (1954a). F. agric. Sci. 44, 340.

Carpenter, K. J., Duckworth, J. \& Ellinger, G. M. (1954b). European Grassland Conference, Paris, 2I-24 Fune 1954, p. 243. Paris: The European Productivity Agency of the Organization for European Economic Co-operation.

Carpenter, K. J., Ellinger, G. M., Munro, M. I. \& Rolfe, E. J. (I957). Brit. J. Nutr. Ir, i6z.

Carpenter, K. J., Ellinger, G. M. \& Shrimpton, D. H. (1954). Proc. Nutr. Soc. 13, xx.

Chalmers, M. I. \& Synge, R. L. M. (1954). Advanc. Protein Chem. 9, 93.

Clegg, K. M. (1957). Personal communication.

Cowlishaw, S. J., Eyles, D. E., Raymond, W. F. \& Tilley, J. M. A. (1956a). F. Sci. Fd Agric. 7, 768.

Cowlishaw, S. J., Eyles, D. E., Raymond, W. F. \& Tilley, J. M. A. (1956b). F. Sci. Fd Agric. 7, 775 .

Duckworth, J. (1952). Chem. E' Ind. p. I 139.

Duckworth, J. (1955). F. Sci. Fd Agric. 6, 240.

Duckworth, J., Ellinger, G. M. \& Shrimpton, D. H. (1955). Unpublished results.

Eggert, R. G., Brinegar, M. J. \& Anderson, C. R. (1953). F. Anim. Sci. 12, 282.

Ellinger, G. M. \& Mitchell, E. B. (I957). Unpublished results.

Evans, R. E. (1952a). F. agric. Sci. 42, 422.

Evans, R. E. (1952b). \%. agric. Sci. 42, 438 .

Evans, R. E. (1954). Y. agric. Sci. 44, 100.

Grau, C. R. \& Kamei, M. (I95o). F. Nutr. 4r, 89.

Heiman, V., Carver, J. S. \& Cook, J. W. (1939). Poult. Sci. 18, 464.

Hill, F. W. \& Dansky, L. M. (1954). Poult. Sci. 33, I 12.

Kratzer, F. H. \& Green, N. (1957). Poult. Sci. 36, 562.

Miller, D. S. (1 956). F. Sci. Fd Agric. 7, 337.

National Institute of Poultry Husbandry (r957). Recommended rations.

National Research Council: Committee on Animal Nutrition (1953). Publ. nat. Res. Coun., Wash., no. 295 .

National Research Council: Committee on Animal Nutrition (1954). Publ. nat. Res. Coun., Wash., no. 301 .

National Research Council: Food and Nutrition Board (1950). Repr. nat. Res. Coun., Wash., no. I 3 I.

Williams, M. A. \& Grau, C. R. (1956). 7. Nutr. 59, 243.

Wolfe, M. \& Fowden, L. (1957). Cereal Chem. 34, 286.

Woodman, H. E. \& Evans, R. E. (1951). F. agric. Sci. 41, 102.

\section{The quantity and quality of protein for human nutrition}

By B. S. Platt and D. S. Miller, Human Nutrition Research Unit, Nutrition Building, National Institute for Medical Research, The Ridgeway, Mill Hill, London,

$$
\text { N.W.7 }
$$

Some of the earliest work on the chemistry and physiology of proteins is associated with the names of Magendie, Mulder, Liebig and Boussingault (Beach, 1948); these men were working and writing in the first half of the nineteenth century. It is exactly roo years ago since Karl Voit, called by Cathcart (192I) 'the master and 
founder of modern metabolic research', published his first work (Voit, 1857). Voit was the first to set up a standard of protein requirements; he recommended for moderately active men $118 \mathrm{~g}$ protein a day. The importance of fats and carbohydrates as well as of protein in the diet was also demonstrated experimentally by Voit. Fifty years ago Karl Thomas (1954) began making experiments on himself which led to a quantitative determination of the biological values of proteins; the essentials of his method are still valid.

Towards the end of his life, Cathcart (I940a,b) delivered the Oliver-Sharpey lectures before the Royal College of Physicians of London on The mystery of alimentation. In these lectures he reminded us of what he called 'the shaky foundations of nutritional knowledge'; and we have to admit that there is still much more work needed before we can be reasonably sure of our ground on the subject of our paper. Out of his intimate knowledge of protein physiology, Cathcart raises a number of points of profound interest; we shall refer to one of these again - 'the assumption ... that the biological value of a protein is something static'. In the same year that these lectures were delivered, a comprehensive statement on the subject of our paper was published by our Chairman, a student of Cathcart (Cuthbertson, 1940-I). Cuthbertson examined several aspects of the subject which we have not time to consider in this communication; his review is valuable as an appreciation of the state of knowledge at the beginning of what may well be regarded as a new phase of progress in protein nutrition.

A brief statement of the recent increase of interest in proteins in nutrition is to be found in the foreword to the report of the proceedings of a conference held in Princeton in 1955 on Human Protein Requirements and their Fulfilment in Practice (Waterlow \& Stephen, 1957). In this report it is stated: 'Terroine emphasized the distinction between the physiological requirement-the minimum amount of protein that will maintain nitrogen balance-and the hygienic requirement-the amount needed under the stresses of everyday life. The former can be defined with precision, as was done by Rose. The latter is at present a matter of guess-work'. Experiments are described in the report, the results of which may also 'provide a rational basis for the concept of a "margin of safety", and so make it possible in the future to define with more precision Terroine's "hygienic requirement" ' (Waterlow \& Stephen, 1957, p. 69).

\section{Report of the FAO Committee on Protein Requirements}

This report $(\mathrm{FAO}, 1957 b)$ is a provisional one and its quantitative recommendations are tentative. The Committee recognizes the tendency to give unjustifiable precision to data on dietary requirements for protein and it has 'tried to counteract this tendency by using careful and guarded phraseology, by hedging its recommendations with the necessary qualifications, and by insisting on the need for further research'. Great credit is due to the Committee for their courage; and not least for what is stated as the main contribution of the report as a whole i.e. 'that it indicates the direction in which the problem of protein requirements is moving'. Two main 
developments in it are $(x)$ the expression of human requirements in terms of a reference protein of high nutritive value; and (2) the adoption of a provisional pattern of essential amino-acids for man which provides a basis for estimating the nutritive value of a diet from its amino-acid composition*. The Committee is fully aware of the difficulties and uncertainties of the subject and therefore of the need for skill, caution and more knowledge in defining protein requirements. Nevertheless it may be fairly claimed that progress has been made in solving the practical problem of planning food production and distribution in relation to the protein needs of populations. This large-scale operation has its special problems; but others, which are in the forefront when individuals and their dietaries are considered, tend to recede when bulk food supplies are examined on a per head basis for a whole population. Our contribution to this Symposium is actuated by the challenge, which this report will constitute for some time to come, to critics to engage in constructive research in this great practical and scientific problem of protein requirements.

\section{Dietary factors in the evaluation of the protein element in human nutrition}

Many of the difficulties of prescribing a diet for the human subject are inherent in the subject rather than in the food; the factors relating to the consumer we shall, however, consider in the next section. So far as the foods are concerned it should eventually be possible to characterize the nitrogenous elements in them so that their 'protein value' may be largely if not entirely determined by chemical or biochemical means. Progress in this direction has been discussed in preceding papers in this Symposium (Bender, 1958; Carpenter, 1958; Ellinger, 1958). The problem is probably an easier one to solve for animal than for human nutrition. For animals, the supply of nutrients for protein metabolism may, in part at least, be simple; often it is in the form of a standardized ration for animals with a restricted and reproducible range of physiological functions with the object of achieving a limited prescribed performance. Even in these circumstances there are still many uncertainties attending the interpretation of data on the protein values of rations, whether these are obtained by chemical, biochemical or biological techniques. A measure of agreement is, however, being reached for the protein values of simple substances determined by different methods. We have, however, not yet solved the problem of how to employ the results of laboratory research in the solution of the problems of protein nutrition in man.

The inherent dietary difficulties when human beings rather than laboratory or commercially-produced animals are concerned are (a) the complexity of the mixtures eaten by man; (b) the nature and timing of snacks and meals; (c) the effect on food values of a wide variety of methods of processing, including cooking; (d) the level in the diet, not only of protein but also of other sources of energy-fats

\footnotetext{
* From data on the essential amino-acid composition of three groups of six different proteins Fisher (1954) has derived figures for the amino-acid composition of 'ideal protein'. It is noteworthy that for six of seven essential amino-acids, the pattern of 'ideal protein' more nearly resembles that of the 'provisional amino-acid pattern' (FAO, 1957b) than does that of the protein of whole egg, cow's or human milk.
} 
and carbohydrates--and of various vitamins and minerals; and (e) the balance between the proteins and several other dietary factors.

Munro (195I) has recently reviewed the relation between proteins and the calorie content of the diet and we need only remark here that in some human dietaries better protein utilization might be achieved by providing additional amounts of either fat or carbohydrate or both, thereby inducing a protein-sparing action. Examples of the enhancing effects of vitamins and minerals on the biological value of protein are to be found in the work of Henry \& Kon (1956) with vitamin $B_{12}$, and that of Menaker (1954) with magnesium salts.

The concentration of protein in the diet is, as will be seen later, important because it may limit the quantity of protein eaten; the biological value of a protein may also alter with changes in the concentration of protein in the diet. Table $r$ illustrates this point, which we mentioned at the beginning of the paper, that the biological value of protein is not static.

Table 1. Variations in biological value of egg protein and casein when given at different levels to weanling rats

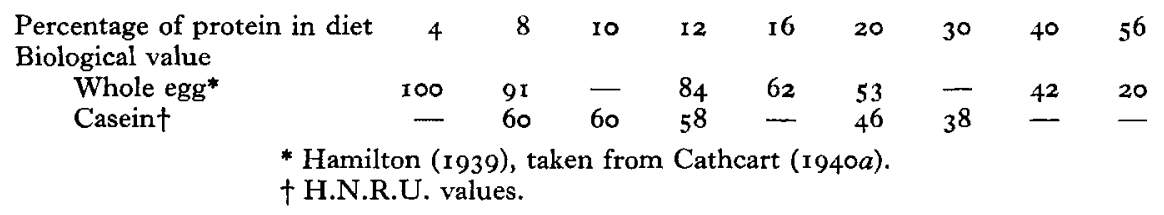

These findings may be disquieting to those accustomed to giving protein to laboratory animals at a fixed level of say $10 \%$; we should add that surveys show that man may have as one extreme less than $6 \%$ protein (Platt, unpublished) in his customary diet and, as the other, as much as $60 \%$ (Cuthbertson, I940-I) on a dryweight basis.

\section{Physiological and pathological factors affecting protein requirements}

Considering now the consumer, we know that protein is needed for the growth as well as for the maintenance of tissues; our knowledge of the average minimum requirements for these purposes is summarized in the FAO (1957b) Report on Protein Requirements. It is well known that proteins in various parts of the body have different amino-acid compositions and turnover rates; we do not, however, know whether the pattern of amino-acid requirements is the same for maintenance as for growth of the young and, therefore, possibly also for the additional needs of the mother during pregnancy and lactation. However, the validity of the methods for the determination of the physiological requirement of an individual for a specified protein or for the essential amino-acids is fairly well established, though we still do not understand, for example, (a) why in Rose's (1957) experiments such a high caloric intake was necessary; (b) why the ratio of the infant to adult requirements per kg body-weight is so much higher when expressed in terms of essential aminoacids (about I0: I for most amino-acids) (Holt, 1957) than in terms of reference 
protein (about $5:$ I) $(\mathrm{FAO}, 1957 b)$; (c) what should be the composition and amount in a diet of nitrogenous matter other than the essential amino-acids; (d) what significance should be attached to the imbalance of amino-acids (Cole, 1956); and (e) what determines the variations in physiological minima for nitrogen of different individuals. This last question may be examined in relation to the 'safe practical allowance' of the FAO Committee which recommends an arbitrary addition of $50 \%$ to the average minimum requirement for reference protein for adults, and an increment of $25-30 \%$ for infants. *

It is debatable whether these correction factors will cover such contingencies as may be envisaged in Terroine's 'hygienic requirement' for protein. The Committee does not budget for the habilitation of the chronically malnourished individual and does explicitly state that it is impossible . . . to make recommendations for requirements for varying acute and chronic pathological states' (FAO, r957b).

This Symposium being on the nutritional value of protein, matters related to the use of protein in the maintenance of health and in the prevention and treatment of diseases may not be strictly relevant; they might indeed be appropriate subjects for discussion at a future meeting of the Society. Protein malnutrition has been widely discussed in the past 15 years; the role of a traumatic factor in the causation of nitrogen loss from the body is discussed by Bull (1958) in this Symposium. The importance of zymotic factors in the production of protein malnutrition has, however, not yet been fully appreciated (Platt, 1953, 1956, 1957; Platt \& Wadsworth, 1956). There is space to mention only two topics. The first is the level of protein nutrition. This level cannot be characterized merely by establishing that the subject is in nitrogen equilibrium, which may be achieved on a low protein intake in an undernourished subject and at the physiological minimum with a higher intake in the normal individual. There is also the question of what constitutes the upper level of protein nutrition; is it a state of eutrophy (a term used by both Cathcart (I940a,b) and Cuthbertson (1940-1) and attributed by the former to Virchow)-if so what is the nature and purpose of the protein stores or reserves? (For discussion of protein stores see Waterlow \& Stephen, 1957, p. 1 I9). The second topic is the possibility that the pathology of protein malnutrition may be a part of the pathology of many diseases. This notion is only an example of a broad view by Cohnheim (I889) (at one time an assistant to Virchow) of the pathology of nutrition--a phrase which is the title of the second volume (written in 1878) of his lectures on general pathology.

\section{Protein values of human dietaries for various types of consumer}

Amalgamating our two approaches, we shall now discuss the protein values of a number of dietaries for various types of consumer. We are confronted with the fact that there are very few measurements of the protein quality of diet as eaten by man. Many and long-continued trials have been made throughout the ages by man on himself, as will be evident, for example, from Cuthbertson's (1940-1) review, though we are not yet able confidently to assess the results. Macrae, Henry \& Kon (1943)

* A second correction factor relates the amount of actual dietary protein of a certain quality to the requirements in terms of the reference protein. 
give data from which may be calculated the net protein utilization (N.P.U.) of foods as eaten in meals served at four R.A.F. stations; but they were tested on rats at an $8 \%$ protein level and the values obtained are probably unduly high. Some data have been obtained with rats in our laboratories (designated H.N.R.U.) for some African diets and for meals eaten in this country. They are given in Table 2.

Table 2. Net protein utilization of some typical U.K. and African diets measured on rats

U.K. diets: R.A.F. stations* based on Ministry of Agriculture, Fisheries and Food: National Food Survey Committee (1957) $\dagger$ individual meals from a canteent

$67,68,71,72$

66

African diets, based on Nicol (1952) †

$62,66,66,73,8 \mathrm{I}$

$40,52,52,53,59$

* Macrae et al. (1943) for four different R.A.F. stations.

† H.N.R.U. results.

The figures in Table 2 have been used to calculate the 'safe practical allowances' in terms of 'reference protein' and dietary protein for male subjects of various ages and for lactating females.

Table 3. Proportion in the diet of total calories needed from protein of different value in terms of net protein utilization for various age and sex groups at two environmental temperatures, $10^{\circ}$ and $25^{\circ}$

\begin{tabular}{|c|c|c|c|c|c|c|c|c|c|c|}
\hline \multirow[b]{4}{*}{ Subject } & \multicolumn{4}{|c|}{$\begin{array}{l}\text { 'Average } \\
\text { minimum } \\
\text { requirement' }\end{array}$} & \multicolumn{6}{|c|}{$\begin{array}{c}\text { 'Safe practical allowance' (protein calories expressed as a } \\
\text { percentage of total calories) }\end{array}$} \\
\hline & \multirow{3}{*}{$\begin{array}{c}\text { Age } \\
\text { (years) }\end{array}$} & \multirow{3}{*}{$\begin{array}{l}\text { for } \\
\text { 'reference } \\
\text { protein'(1) } \\
\text { (g) }\end{array}$} & \multirow{2}{*}{\multicolumn{2}{|c|}{$\begin{array}{l}\text { Calorie requirement } \\
(\text { Cal. })\left({ }^{2}\right)\end{array}$}} & \multicolumn{3}{|c|}{ At $10^{\circ}$} & \multicolumn{3}{|c|}{ At $25^{\circ}$} \\
\hline & & & & & & & & & & \\
\hline & & & $\overparen{\text { At } 10^{\circ}}$ & $\widehat{\text { At } 25^{\circ}}$ & $\begin{array}{l}\text { N.P.U. } \\
100\left({ }^{3}\right)\end{array}$ & $\begin{array}{l}\text { N.P.U. } \\
80\left({ }^{4}\right)\end{array}$ & $\begin{array}{l}\text { N.P.U. } \\
69\left({ }^{5}\right)\end{array}$ & $\begin{array}{l}\text { N.P.U. } \\
100\left({ }^{3}\right)\end{array}$ & $\begin{array}{l}\text { N.P.U. } \\
62\left({ }^{8}\right)\end{array}$ & $\begin{array}{l}\text { N.P.U. } \\
40\left({ }^{7}\right)\end{array}$ \\
\hline \multirow[t]{6}{*}{ Male } & 2 & I 5.8 & 1300 & 1203 & $7 \cdot 5$ & $9 \cdot 4$ & 10.9 & $8 \cdot I$ & $13 \cdot 1$ & $20 \cdot 3$ \\
\hline & 5 & I 5.9 & 1700 & I 573 & $5 \cdot 8$ & $7 \cdot 3$ & $8 \cdot 4$ & $6 \cdot 2$ & 10.0 & I 5.5 \\
\hline & 8 & r 9.3 & 2100 & 1943 & $5 \cdot 7$ & $7 \cdot 1$ & $8 \cdot 3$ & $6 \cdot 1$ & $9 \cdot 8$ & 15.3 \\
\hline & I I & $25 \cdot 5$ & 2500 & 2313 & $6 \cdot 3$ & $7 \cdot 9$ & $9 \cdot 1$ & $6 \cdot 8$ & $11 \cdot 0$ & $17 \cdot 0$ \\
\hline & 14 & 40.6 & 3100 & 2868 & 8.0 & 10.0 & $x \times 6$ & $8 \cdot 7$ & 14.0 & $21 \cdot 8$ \\
\hline & 25 & $22 \cdot 7$ & 3200 & 2960 & $4 \cdot 4$ & $5 \cdot 5$ & $6 \cdot 4$ & $4 \cdot 7$ & $7 \cdot 6$ & II 8 \\
\hline \multirow{2}{*}{\multicolumn{11}{|c|}{$\begin{array}{l}\text { Lactating } \\
\text { female }\end{array}$}} \\
\hline & & $49 \cdot 3$ & 3300 & 3127 & $9 \cdot 2$ & I I 5 & I 3.3 & $9 \cdot 7$ & I 5.6 & $24 \cdot 3$ \\
\hline & $\begin{array}{l}\text { N.P.U. } \\
{ }^{1} \text { Calcul } \\
{ }^{2} \text { From } \\
{ }^{3} \text { As 're } \\
{ }^{4} \text { Count } \\
{ }^{3} \text { Mean } \\
{ }^{6} \text { Count } \\
{ }^{7} \text { Nigeri } \\
\text { tot }\end{array}$ & $\begin{array}{l}=\text { net prote } \\
\text { lated from w } \\
\text { FAO (r957o } \\
\text { ference prot } \\
\text { try A (F.A.O } \\
\text { value for R. } \\
\text { try C (FAO, } \\
\text { ian farmers' } \\
\text { al calories de }\end{array}$ & $\begin{array}{l}\text { in utiliza } \\
\text { eights of } \\
\text { x). } \\
\text { ein'. } \\
\text { A. F. diet } \\
1957 b \text { ) } \\
\text { diet from } \\
\text { erived fro }\end{array}$ & $\begin{array}{l}\text { from Mac } \\
\text { inpublishec }\end{array}$ & rae et al. & $\begin{array}{l}(943) ; i \\
d \text { on a } s\end{array}$ & $\begin{array}{l}8 \% \text { pr } \\
\text { rvey by }\end{array}$ & $\mathrm{m} F A C$ & 1957b) & \\
\hline
\end{tabular}

Table 3 , shows the relatively high needs of the very young child, the adolescent and the nursing mother. Wheat contains about $13 \%$ protein calories, and a child on a diet with wheat as the staple, is likely to satisfy his protein requirements. In fact it would be difficult where wheat is the staple to construct a diet from the poorest larder that did not contain about $11 \%$ protein calories. In sharp contrast, the 
dietaries of tropical peoples having starchy roots, tubers or fruits (e.g. cassava, sweet potatoes, yams, plantains or bread-fruit) as the staple article not only have a low, but often a very low, proportion of protein calories.

Table 4 gives the amounts of various foods in forms that would have to be given to a 2-year-old child to supply his protein needs according to the recommendations in the FAO Report (FAO, I957b).

\section{Table 4. Amount and energy content of various preparations needed to meet protein} needs of a 2-year-old child

('Safe practical allowance' (FAO, 1957b) I5.8 $\times$ I.5 g reference protein; calorie requirement (FAO, 1957a) г 203 Cal.)

\begin{tabular}{|c|c|c|c|}
\hline Preparation & N.P.U.* & Amount & $\begin{array}{l}\text { Energy content } \\
\text { (Cal.) }\end{array}$ \\
\hline Gruel: $20 \%$ sorghum meal in water & 50 & $2 \cdot 31$ & $1,6 \pm 6$ \\
\hline $20 \%$ maize meal in water & 40 & $3 \cdot I 1$. & 2,219 \\
\hline $20 \%$ cassava meal in water & $5 \circ+$ & $15 \cdot 71$ & 10,673 \\
\hline Bread ( $85 \%$ extraction) & 40 & $591 \mathrm{~g}$ & 1,327 \\
\hline Milk: cow's & Ioot & 0.71 & 427 \\
\hline human & $100 t$ & 1.71. & 1,194 \\
\hline
\end{tabular}

It is obvious from these data that, possibly with maize, and most certainly with cassava pap, the volume of the infant stomach must be a limiting factor in adequate protein nutrition of the young child. The necessity in these circumstances of providing protein-rich foods is clear; they may be most conveniently and desirably provided as human milk (Platt, 1954 ) but where the diet is low in protein the problem of extra supplies of good protein is simply shifted to the mother, who can, however, utilize cruder sources of supply than can the young child.

\section{Some practical implications}

This concluding section may be prefaced with the reminder that the paramount property of a good diet is the adequate level and balance of all the nutrients.

Another reminder is that the 'menu value' of foods is as important as quality, and this should not be overlooked, particularly since the nature of the protein in a food is often identified with its palatability and acceptability.

Our deliberations have also a direct bearing on the food economy of a community, and the implications for animal husbandry of the contributions of Carpenter (I958) and Ellinger ( $195^{8}$ ) are clear, particularly in predominantly agricultural countries where plans for food and fodder production should be intimately related to the quantity and quality of protein needed.

Finally, the effects of processing of foods, including cooking, and of storage on the protein value of foods should be determined; it is indeed in this context, i.e. of food technology, that the measurement of biological value by the classical techniques is particularly appropriate and straightforward. 


\section{Concluding remarks}

A criticism of our contribution might be that too many questions have been posed and too few problems solved. Nevertheless, the state of knowledge in which it is possible to frame worth-while questions is one in which there is hope of finding answers to them within a reasonable time. For the benefit of those who are comparative newcomers to this field we have deliberately mentioned work done from 50 to I 50 years ago. Some of this old work is very good and much of it is highly relevant to present-day problems-and would repay examination. Lastly, it may not be inopportune to remark that though the fields of human and animal nutrition have much in common and efforts in both can be mutually beneficial, there are differences in aims and interests which should be clearly recognized and-may we say-respected.

\section{REFERENCES}

Beach, E. F. (1948). In Proteins and Amino Acids in Nutrition, p. I. [M. Sahyun, editor.] New York: Reinhold Publishing Corp.

Bender, A. E. (1958). Proc. Nutr. Soc. 17, 85 .

Bull, J. P. (1958), Proc. Nutr. Soc. 17, 114.

Carpenter, K. J. (1958). Proc. Nutr. Soc. 17, 91.

Cathcart, E. P. (I921). The Physiology of Protein Metabolism, p. 3. London: Longmans, Green \& Co.

Cathcart, E. P. (1940a). Lancet, 238, 533.

Cathcart, E. P. (I $940 b$ ). Lancet, 238, 586 .

Cohnheim, J. (1889). Lectures on General Pathology. London: The New Sydenham Society.

Cole, W. H. [editor] (1956). Some Aspects of Amino Acid Supplementation. New Brunswick, U.S.A.: Rutgers University Press.

Cuthbertson, D. P. (1940). Nutr. Abstr. Rev. 10, 1.

Ellinger, G. M. (1958). Proc. Nutr. Soc. x', roo.

FAO (1957a). F.A.O. nutr. Stud. no, I5.

FAO (1957b). F.A.O. nutr. Stud. no, I6.

Fisher, R. B. (1954). Protein Metabolism. London: Methuen \& Co.

Hamilton, T. S. (1939). F. Nutr. 17, 565.

Henry, K. M. \& Kon, S. K. (1956). Brit. F. Nutr. ro, 39.

Holt, L. E. (1957). In Human Protein Requirements and their Fulfilment in Practice. Proceedings of a Conference in Princeton, United States (1955) sponsored jointly by FAO/WHO/Josiah Macy Jr. Foundation. [J. C. Waterlow and J. M. L. Stephen, editors.] p. 25.

Macrae, T. F., Henry, K. M. \& Kon, S. K. (r943). Biochem. F. 37, 225.

Menaker, W. (1954). Proc. Soc. exp. Biol., N.Y., 85, 149.

Miller, D. S. \& Bender, A. E. (1955). Brit. F. Nutr. 9, 382.

Ministry of Agriculture, Fisheries and Food: National Food Survey Committee (1957). Domestic Food Consumption and Expenditure, 1955. London: H.M. Stationery Office.

Munro, H. N. (195 I). Physiol. Rev. 31, 449.

Nicol, B. M. (1952). Brit. F. Nutr. 6, 34.

Platt, B. S. (1953). Int. Congr. trop. Med. Malaria. v. Istanbul, p. 155.

Platt, B. S. (1954). Proc. Nutr. Soc. 13, 94.

Platt, B. S. (1956). In British Postgraduate Medical Federation, Lectures on the Scientific Basis of Medicine. Vol. 4, p. 145. London: Athlone Press.

Platt, B. S. (1957). Amer. F. trop. Med. 6, 773.

Platt, B. S. \& Wadsworth, G. R. (1956). Proc. Nutr. Soc. 15, 103.

Rose, W. C. (1957). Nutr. Abstr. Rev. 27,631.

Scott, J. A. (1955). Report on the Heights and Weights of School Pupils in the County of London in 1954. London: London County Council.

Thomas, K. (1954). Annu. Rev. Biochem. 23, I.

Voit, K. (1857). Physiologisch-Chemische Untersuchungen. Augsburg.

Waterlow, J. C. \& Stephen, J. M. L. [editors] (1957). Human Protein Requirements and their Fulfilment in Practice. Proceedings of a Conference in Princeton, United States (1955) sponsored jointly by FAO/WHO/Fosiah Macy Fr. Foundation.

17 (1) 9 